\title{
Socio-ecological aspects of the realization of the human potential of workers in resource- producing regions
}

\author{
Hasan Gafarov ${ }^{*}$, Iuliia Gafarova ${ }^{1}$, Anton Belkov², Rachid Bikmetov², and Vladimir \\ Zolotukhin $^{2}$ \\ ${ }^{1}$ Belarusian State University, Department of Communicative Design, Faculty of Social and Cultural \\ Communications, 220036, Minsk, K. Liebknecht Street, 92, Belarus \\ ${ }^{2}$ T.F. Gorbachev Kuzbass State Technical University, Department of History, Philosophy and Social \\ Sciences, 650000 Kemerovo, 28 Vesennyaya st., Russian Federation
}

\begin{abstract}
One of the problems of resource-producing regions, both in Russia and in other countries, is provision of industrial enterprises with professional personnel. It has an impact on the development of socioeconomic infrastructure, the degree of technological development, the state of the environmental situation and other aspects. Depending on the state structure and socio-political situation, these problems have their own specifics, in particular, it concerns the coal industry of Kuzbass in the XX$\mathrm{XXI}$ centuries. In the XX century, the formation of human resources was first ensured by free recruitment, organized recruiting and party mobilizations. It is emphasized that under these conditions, the state authorities and the party leadership were forced to make a decision to use the labor of special settlers, labor settlers, home front soldiers, as well as the labor of Soviet Germans deported to Kuzbass at industrial facilities, including at coal industry enterprises. At the end of the XX - beginning of the XXI century, there is a change in the approaches to the formation of human resources, depending on the socio-economic, demographic and other conditions of the development of modern Russia. The problems of the formation and development of industry, the dynamics of human resources potential and demographic changes in Western Siberia were considered in the works of A. B. Konovalov, S. V. Soboleva, E. M. Shcherbakova, and others. Climatic conditions, the lack of basic household infrastructure, staff turnover on the one hand, and the lack of environmental standards on the other, have led to inefficient socioeconomic regional development and an increase in environmental problems. In modern conditions, this is manifested not only in the growth of oncological diseases in Kuzbass, but also in the degree of environmental pollution by industrial waste, including the tendency to alienate agricultural land for the construction of technological roads, warehouses for the fertile soil layer and sites for auxiliary equipment. Attention is focused on the fact that for the rise of industry and the increase in coal production, it was necessary to attract labor, and the demographic situation is contradictory: on the one hand, the dynamics of the natural birth rate of the population decreased, which was a characteristic phenomenon for all
\end{abstract}

* Corresponding author: hassangafarov@gmail.com 
regions of Western Siberia, and on the other, the lack of labor resources was compensated due to internal migration processes.

\section{Introduction}

In the middle of the XX century, in connection with the socio-economic and political processes, the problem of forming the industrial potential that ensures the economic security of the USSR was acute. This problem is peculiar to the Kuzbass coal basin, the development of which required the concentration of enormous material, technical, technological and, especially, human resources. The development of the available natural resources required the involvement of professional personnel, the solution of sociodemographic problems, as well as the forms and methods of disclosure of human capital within the existing party-nomenclature system.

\section{Material and Method}

To reveal the demographic and socio-cultural aspects of the development of the human potential of coal industry workers of the XX century, works on the history of industrial development, the dynamics of labor resources and migration processes in Western Siberia were used (A. B. Konovalov, S. V. Soboleva, E. M. Shcherbakova, O. B. Dashinamzhilov, and others). The preserved statistical data of the USSR and international organizations contributed to the disclosure of the issues of the formation of human resources, the dynamics of the development of urban and rural populations, as well as demographic changes. The ideas of K. Krippendorf on the interdependence of the social environment, ecology and industrial design and historical and cultural retrospect are used. This allowed us to focus on the problems of human development of the population of Kuzbass and, in particular, the workers of the coal industry in the middle of the XX century. Within the framework of the study of this problem, the following methods were used: rational-logical analysis, structural-functional approach, conceptual analysis, historical and logical comparison, generalization, as well as the method of hypotheses with their subsequent verification.

\section{Results and Discussion}

The economic basis of the fuel and metallurgical complex of Kuzbass was laid back in the 30s of the XX century. It includes: the Kuznetsk Metallurgical Plant, coal enterprises of Anzhero-Sudzhensk, Prokopyevsk-Kiselevsk districts, Kemerovo and Leninsk mines, Osinniki and Aralichevsk mines, coal quarries in Salair, Telbess and Temir-Tau, the reconstructed Guryevsk Metallurgical Plant. Various ways and methods were used to form it. First of all, we are talking about organized recruitment conducted by state authorities. Its specific feature was the attraction of unskilled labor from rural areas of Western Siberia. But, despite the active work of recruiters and the provision of benefits and monetary remuneration, only $53.4 \%$ of the planned amount was attracted [1]. Graduates of mining schools were attracted to work on the new coal mining equipment. Due to the lack of qualified personnel (instead of the declared 44 thousand skilled workers in 1934, coal enterprises received 1,814 people), coal enterprises were forced to independently train personnel from among the new workers [2, P. 142].

The recruitment of people, the free hiring and organization recruitment, the sending of graduates of mining and technical schools and colleges, carried out on the initiative of the 
Communist party and Komsomol structures, could not adequately solve the problem of personnel. Objectively, there were two reasons. First, the small number of the population, which did not have basic technological skills. Secondly, the climatic conditions, the distance from the railway and road transport infrastructure. Due to the low qualification of labor resources, there was a risk of using the equipment for other purposes and in violation of basic environmental requirements, not only in relation to the person himself, but also to the environment. To this must be added the shortage of housing and children's institutions, poor medical and commercial services, poor organization of food, labor and everyday life. This situation was the reason for the use of various categories of special equipment, especially since there was an opportunity to select the use of qualified personnel. For example, in accordance with a secret resolution of the West Siberian Regional Committee of the CPSU (Bolsheviks) of December 5, 1931, a decision was made to concentrate only one Kiselevka up to 10,000 exiles at the new mines [3, P. 5]. In total, in 1930-1932, 23,630 families of special settlers numbering 61 thousand people arrived in Kuzbass from different regions of the USSR. In each family, as a result of the selection in Omsk, there should have been at least 2 (two) adult able-bodied family members. All of them were sent to work in the coal and metallurgical industries.

The use of the so - called "home front militia" - persons of military age from families deprived of electoral rights-has also become widespread in Kuzbass. Their military service was replaced by labor activity in the mines of the region. At the end of 1930, the first parties of the home front militia arrived at the mines in the amount of 2,454 people, united in 4 non-military detachments. At the beginning of 1937 the home front militia units were reorganized into construction units of the Red Army and removed from coal mining [4, P. 176-182]. They were sent to work in the Anzherka, Kemerovo, Leninsk and Prokopyevsk mines. Their status was similar to that of a labor settler.

A special role in the composition of the special contingent in the mines of Kuzbass was assigned to the soviet Germans who were deported in September 1941 from their places of residence on the territory of the Western European part of the USSR. In accordance with the decision of the Novosibirsk Regional Committee of the CPSU (Bolsheviks) of September 6, 1941, almost a quarter of the soviet Germans deported to the region - 24,600 people - were sent to Kuzbass [5]. The additional November mobilization of soviet Germans in 1943, which included German men aged 15 to 55 and women aged 16 to 45 , also significantly expanded the mining cadres of Kuzbass. Permission for the families of the mobilized to move to Kuzbass and the provision of housing for them increased the influx of the German population to the region. And as a result, in accordance with a number of resolutions of the State Defense Committee, the mobilized Germans were assigned to the permanent personnel of the region's industry with all the industry benefits due (No. 9526c of 18.07 .1945 , No. 8133 of 13.04 .1945 , etc.).

Upon completion of the construction and commissioning of the mines of large enterprises of the coal industry, the relationship of enterprises with the local bodies of the NKVD (People's Commissariat of Internal Affairs) changed, namely, they retained control over prisoners, their movement from one site to another, especially to another locality. The negative aspect of such changes was the acute shortage of housing, because the administration of the mines was limited only to the allocation of improvised building materials. The first special settlements around the mines were large arrays of poorly adapted rooms without windows and stoves, hastily made wicker-filled barracks, or even just huts and dugouts. A significant factor is that " the decrease in working capacity due to fatigue during long work shifts, which leads to a decrease in labor productivity, staff errors during the operation of complex production facilities of increased danger» $[6,53]$. From this point of view, it would not have made any sense to talk about the development of social and other infrastructure in the middle of the last century, if this was not the dominant reason 
for the formation and/or degradation of the current socio-ecological situation for resourceproducing regions.

From the point of view of social interactions between different types of artifacts by Kenneth Boulding [7, P. 77-88], mutual cooperation within the framework of regional social dynamics has the ability to support one artifact by another and, in turn, be supported by this artifact. An example of mutual cooperation, as a result of which environmental values are formed, is the interdependence of the extraction of minerals (coal, etc.) and their consumers. Increasing the production of minerals requires increasing the quantity and improving the quality of mining equipment, which, in turn, contributes to the improvement of technologies. According to Krippendorf, it should be taken into account that "projects that encourage mutual cooperation between different technologies increase the chances of others to survive" [8, P. 201]. This shows, in any case, the balance of social development, although for the Soviet realities it is contradictory, aiming at the inefficient use of human capital by state institutions.

Significant changes in the composition of the mining personnel occurred during the Great Patriotic War. After the occupation of the Donbass, and then the Moscow basin, Kuzbass had to provide the country's economy with coal. Due to the fact that during the first six months of the war, 11,856 miners left Kuzbass for the Red Army [5], in July 1942, the total shortage of labor in the Kuzbass mines was 34,583 people. Due to the lack of internal labor resources, it became necessary to look for them outside of Kuzbass. The organized recruitment and free hiring of workers were replaced by the planned distribution of personnel evacuated from temporarily occupied areas, labor mobilization to industrial enterprises through military enlistment offices, and the sending of students from factory training schools and vocational schools [2, P. 153]. Mobilizations activity from the Communist Party and the Komsomol also played a significant role in providing personnel for the Kuzbass mines. For example, only the August mobilization of 1942 allowed 6 thousand new workers to join the mining cadres [2, P. 153-153].

In military conditions, the labor use of a number of categories of special equipment has increased as one of the sources of replenishment of working personnel, which does not require significant material costs and guarantee consolidation. The satisfaction of the demand for an increase in coal production due to a lack of personnel was called into question. Therefore, at the government level, was decided to continue replenishing human reserves by further increasing the number of labor settlers in the industry. The question of the degree of involvement of representatives of the special contingent, soviet Germans, etc. in the existing socio-cultural environment, the possibility of defending their rights and interests to create basic living conditions, labor protection, etc., was significant. Political and socio-economic dependence was a characteristic feature not only for representatives of these categories, but also for the population as a whole. A characteristic feature was the degree of legal insecurity of employees' work. The existence of benefits and privileges was determined depending on the degree of qualification, the availability of education, the desire and realization of the opportunity to integrate into the everyday socio-cultural environment, because "if people do not want to contact, we cannot force them to do so" [9].

At the same time, a certain level of knowledge was disseminated through the mass media, Communist party and administrative bodies, and the information transmitted by them was accompanied by well-known "signs of doubt" [10, P.9]. To a certain extent, this had an impact on social stratification, both depending on the unevenly distributed valuable social resources (J. H. Turner) [11], and the dominance of emotional stratification as a result of R. Tamm's sociostructural differentiation [12].

The ongoing processes (organizational recruitment, voluntary mobilization, the existence of special camps, etc.) allowed the regional authorities to conduct socio-economic policy within the framework of fulfilling its goals and objectives, as well as to regulate the 
demographic situation aimed at preserving the regional labor resources. In this regard, the problem of depopulation of the population becomes urgent, because "the active reproductive period is entered by small generations born already in post-Soviet Russia with the worst state of health, including reproductive, and the age older than the able-bodied relatively numerous generations born in the late 1950s - early 1960s" [13, P.797]. We are talking about the indigenous population, immigrants as the founders of ethno-national, cultural (German, Ukrainian and other settlements) and other entities created by "their" educational and pedagogical bodies, including self-government bodies. This contributed to the formation of a certain level of technological culture on the basis of existing material, organizational and other resources. These processes were significantly influenced by the simultaneous presence of different cultures, which left an imprint on the further formation of the daily mentality of the regional society, not only within the framework of increasing mining, building urban infrastructure without taking into account economic expediency [14], environmental standards [15], but also issues of reproduction of labor resources [16] within the framework of ideological paradigms [17].

The negative dynamics of migration processes associated with the need to replenish labor resources has had and still has an impact on modern demographic processes [18]. We are talking about the natural decline of the population ("The steady migration decline of the population is observed in the Siberian Federal District, although it is less than in the Far Eastern Federal District (-4.5\%)" [19]) and regional demographic security, which is characterized by the presence of social tension. The total birth rate in urban settlements of the RSFSR and the regions of Western Siberia in 1978/1979-1982/1983, in particular the Kemerovo region, was 1.659-1.797 [20, P. 179], the migration turnover of urban settlements in 1985.189 was at the level of 22.3-22.7 \% [20, P. 276]. Speaking about the level of demographic security, it should be noted that for the regions of the Siberian Federal District, its jump occurred in 1990-1995. In particular, over 5 years, the level of demographic danger for the Kemerovo Region increased from 0.58 to 0.88 [21, 18]. During the period 1989-2002, the number of Russian population in the Siberian Federal District (Altai Krai, Kemerovo, Tomsk, Novosibirsk regions) "decreased at the highest rate" [22].

From the end of the Great Patriotic War to the 70s, the forces of prisoners of war and internees carried out work, the cost of which amounted to about 500 million rubles. In Stalinsk, the prisoners of war built such facilities as: mines "Zyryanovskaya" and "Abashevskaya" (Trust "Kuznetskugol"), "Krasnogorskaya", No. 7/B (Trust "Kaganovichugol"), a brick factory in the village of Baidaevka (Trust "Kuznetskugol"), two concentrating plants, the 3rd and 4th stages of the thermal power plant of the Stalin Aluminum Plant (Trust "Kuznetsktyazhstroy"), a large residential area of Stalin Metallurgical Plant in the area of Voroshilovsky Highway and on Molotov Avenue (20 buildings); their forces were carried out the construction of Suvorov, Vorobyov, Kutuzov, Pirogov and many others streets. The Palace of Pioneers, a music school in Prokopyevsk, a mechanized brick factory in the village of Krasnaya Gorka, glass and military factories in Yurga were built. Many residential buildings were built by prisoners of war in the Central, Rudnichny and Zavodsky districts of Kemerovo, the communal bridge over the Tom River.

It should be noted that foreign prisoners of war became active participants in industrial and civil construction in the territory of the cities of Kuzbass, because the unsatisfactory work of construction trusts was recorded. The party leadership of the region has developed a program of housing construction. The state archive notes that a special role in the construction was assigned to special camps organized under the Trusts "Kemerovozhilstroy" (Kemerovo) and "Kuzbasszhilstroy" (Stalinsk), which allowed the formation of a certain level of infrastructure. In total, they had to build and put into operation 30,000 square meters of housing for miners, metallurgists and chemists of Kuzbass. Both camps were organized in accordance with the Resolution of the Council of 
Ministers of the USSR No. 1898 of August 25, 1946 and the order of the Ministry of Internal Affairs of the USSR No. 349 of September 4, 1946. These were small camps, consisting of several camp points (construction sites). On January 1, 1948, their number reached 5109 and 10184 people, respectively [24, P. 194].

Studying the problems accumulated during the XX century, it is worth noting that the formation of the Kuzbass industrial complex did not take into account the geodemographic factor as a core condition for the development of demographic processes and the state and preservation or destruction of the natural and climatic habitat, which ultimately affects the development and disclosure of human potential in parallel with the development and improvement of technologies in the framework of cooperation or competition ( $\mathrm{K}$. Krippendorff) of a person with the environment. Both the dynamics of complex and contradictory demographic processes in different historical periods, as well as the opportunities for the disclosure of human capital, were and still are influenced by the migration policy of the state [25], which ultimately determines not only the preservation of the environment, but also national identity and state security. From this point of view, environmental problems should be considered within the framework of the a-etic unity of "nature" with the natural attitude of consciousness [26], which, based on the concept of the "life world" and everyday experiences, implements a positive or negative solution to it (environmental problems).

In modern Russia, as in the leading Western countries, the analysis of the nature and content of the sovereignty of the state practically does not take into account the geodemographic factor. These are the demographic prospects of the state and, above all, the core super-ethnos, the level of uniformity and heterogeneity of the population; the state of the natural and climatic habitat, including the resource base and the entire ethno-feeding landscape. Meanwhile, the geography, history and demography of the state are the basic sources of ensuring the sovereignty, territorial integrity and national security of the country. At present, the geodemographic factor remains the fundamental condition for the survival, self-preservation and retention of the Russian statehood.

\section{Conclusion}

The dynamics of demographic and socio-economic processes in the middle and end of the XX century in Western Siberia suggests that the reasons for the socio-economic and technological lag in regional development are associated not only with historical events, but also with the decisions that are taken at the present stage of regional socio-economic development. We are talking about the dynamics of the development of large (city-forming) industrial enterprises with the processes of alienation of agricultural land for the construction of technological roads, warehouses for the fertile soil layer and sites for auxiliary equipment. These processes will have an impact on the infrastructure and social development of the industrial centers of the Kemerovo Region.

\section{References:}

1. Gosudarstvenniy arhiv Novosibirskoy oblasti, call. 981, aids 1, fol. 73, P. 224; call. 12, aids 3, fol. 276, P. 27-29

2. Coal industry of Kuzbass. 1721-1996 (Kemerovo Book Publishing House, Kemerovo, 1997)

3. V. N. Galkin, L. I. Gvozdkova, R. S. Bikmetov, B. I. Berlintager, Unknown Kuzbass. Issue 2. Totalitarian system: executioners and victims. (Kemerovo, 1995)

4. S. A. Krasilnikov, Tyloopolchentsy, Eco., 3, 176 (1994) 
5. Gosudarstvenniy arhiv Novosibirskoy oblasti, call. P-4, aids 34, fol. 171

6. Russia: trends and prospects of development. Yearbook. Issue 13 (Moscow, 2017)

7. K. E. Boulding, Ecodynamics: A New Theory of Societal Evolution. (Beverly Hills, CA: Sage Publications, 1978)

8. K. Krippendorff, The Semantic Turn; A New Foundation for Design (Boca Raton, London, New York: Taylor\&Francis, CRC Press, 2006)

9. R. Zapata-Barrero, Comparative Migration Studies, 5 (2017)

10. N. Luhmann, Die Realität der Massenmedien, N. Luhmann, Opladen: Westdeutscher Verlag (1995)

11. J. H. Turner, Emotions and Social Structure: Toward a General Sociological Theory, Social structure and emotion (J. Clay-Warner \& D. T. Robinson. San Diego, CA 2008)

12. R. Thamm, Sociological Perspectives, 35(4), 649 (1992)

13. S. V. Soboleva, O. V. Chudaeva, Russia: trends and prospects of development, 13, 1, 797 (2018)

14. T. I. Gritskevich, E. F. Kazakov, A. B. Konovalov, European Works on Social and Behavioral Sciences, XXXV, 402 (2017)

15. T. V. Galanina, M. I. Baumgarten, V. G. Mikhailov, T. G. Koroleva, G. S. Mikhailov, IOP Conference Series: Earth and Environmental Science, 50, 012030, 1 (2017)

16. S. Kovalevsky, N. Ravochkin, V. Shchennikov, E3S Web of Conferences, 41, 04035 (2018)

17. M. Yazevich, O. Kalinina, O. Zhironkina, E3S Web of Conferences 134, 03004 (2019)

18. A. Bel'kov, V. Zolotukhin, N. Zolotukhina, N. Sedina, M. Kozyreva, E3S Web of Conferences 134, 03005 (2019)

19. E. Shcherbakova, Demoscope weekly, 805-806 (2019)

20. O. B. Dashinamzhilov, The urban population of Western Siberia in the 1960s-1980s: a historical and demographic study (Novosibirsk: Publishing House of the Siberian Branch of the Russian Academy of Sciences, 2018)

21. S. V. Soboleva, N. E. Smirnova, O. V. Chudaeva, Bulletin of the Novosibirsk State University of Economics and Management, 1 (2016)

22. S.V. Soboleva, N.E. Smirnova, O.V. Chudaeva, Regional Research of Russia, 10(2), $220(2020)$

23. Gosudarstvenniy arhiv Kemerovskoy oblasti, call. 143, aids 3, fol. 706, p. 1.

24. The system of correctional labor camps in the USSR, Reference Book, (Moscow: Links, 1998)

25. E. M. Shcherbakova, Demoscope Weekly, 895 (2021)

26. A. S. Skutin, L. N. Shabatura, Bulletin of the Novosibirsk State University of Economics and Management, 2, 347 (2014) 